Research Article

\title{
Simultaneous Determination of Hydrochlorothiazide and Losartan Potassium in Pharmaceutical Product by UV-Vis Spectrophotometric Method with Kalman Filter Algorithm
}

\author{
Tran Thuc Binh $\mathbb{D}^{1},{ }^{1}$ Le Thi Phuong Tram, ${ }^{1}$ Nguyen Van Hop, ${ }^{1}$ Nguyen Dang Giang Chau, \\ Nguyen Duy Luu, ${ }^{2}$ and Nguyen Thi Quynh Trang ${ }^{3}$ \\ ${ }^{1}$ University of Sciences, Hue University, Hue 530000, Vietnam \\ ${ }^{2}$ Da Nang University of Medical Technology and Pharmacy, Da Nang 550000, Vietnam \\ ${ }^{3}$ Faculty of Environmental Sciences, Saigon University, Ho Chi Minh City 700000, Vietnam
}

Correspondence should be addressed to Tran Thuc Binh; ttbinh@hueuni.edu.vn

Received 11 June 2021; Revised 30 June 2021; Accepted 12 July 2021; Published 21 July 2021

Academic Editor: Cecilia Cagliero

\begin{abstract}
Copyright (c) 2021 Tran Thuc Binh et al. This is an open access article distributed under the Creative Commons Attribution License, which permits unrestricted use, distribution, and reproduction in any medium, provided the original work is properly cited.

In this paper, hydrochlorothiazide (HCT) and losartan potassium (LSP) in tablets are simultaneously determined with UV-Vis spectrophotometry and chemometrics without separation. The spectra of standard and sample solutions were recorded in the wavelength from 220 to $300 \mathrm{~nm}$ at $1.0 \mathrm{~nm}$ intervals. The concentrations of HCT and LSP in the sample solutions were computed with the Kalman filter algorithm written on the Microsoft Excel 2016 and Visual Basic for Applications (VBA) platform. The method validation was determined via the accuracy and repeatability of measurements when analyzing HCT and LSP in the Splozarsin Plus tablet and comparing the mean values of their contents in the sample with those analyzed with HPLC. The proposed method is simple with a low cost compared with the standard HPLC method.
\end{abstract}

\section{Introduction}

Molecular absorption spectrometry incorporating chemometrics is often used to determine components in a mixture with overlapping spectra simultaneously. The general principle of this combined method is that the full-spectral data are loaded into software programmed with algorithms and statistical methods, from which each component in the mixture is quantified. Due to its simplicity, the method is considered environmentally friendly and economical. Besides, full-spectral data for calculations combined with algorithms help to increase the accuracy of the determination. Standard chemometrics methods include classical least squares (CLS), partial least squares (PLS), Kalman filter, principal component regression (PCR), artificial neural networks (ANNs), and derivative spectrophotometry. These methods have been studied and applied to various matrices [1-7].
In our previous study [4], we succeeded in employing the Kalman filter algorithm with full-spectral measurement to build a program (written on the Microsoft Excel 2016 and Visual Basic for Applications (VBA) platform) for determining the concentration of substances in a mixture. Inheriting these results, we continue modifying and applying this combined method (from now on, Kalman-Excel method) to determine Hydrochlorothiazide (HCT) and Losartan Potassium (LSP) in Splozarsin Plus simultaneously. Hydrochlorothiazide $\left(\mathrm{C}_{7} \mathrm{H}_{8} \mathrm{ClN}_{3} \mathrm{O}_{4} \mathrm{~S}_{2}, M=297.7 \mathrm{~g} / \mathrm{mol}\right)$ is a diuretic medicine (or water pills) used to treat hydronephrosis, renal failure, or nephropathy. In addition, HCT is also used effectively to prevent and treat hypertension, liver disorders, myocardial infarction, heart failure, or stroke in patients with cardiovascular problems. Losartan Potassium $\left(\mathrm{C}_{22} \mathrm{H}_{22} \mathrm{ClKN}_{6} \mathrm{O}, M=461.0 \mathrm{~g} / \mathrm{mol}\right)$ belongs to a class of medicine called angiotensin receptor blockers that dilate blood vessels, facilitating blood to flow more easily. Losartan 
Potassium is used to treat high blood pressure and heart failure and help to protect the kidney damage caused by diabetes [8-10].

For the determination of HCT and LSP in medicine, various techniques have been developed elsewhere. Maggio et al. [8] established a procedure based on the multivariate analysis of spectral data in the $220-274 \mathrm{~nm}$ region, with the partial least square algorithm. The results agreed well with those determined with HPLC. Rathee et al. [9] developed Vierordt's and $\mathrm{Q}$ absorbance ratio methods. They were successfully applied to the assay of LSP and HCT in tablet formulations. Rao et al. [10] built three techniques for this purpose: (1) to solve the equations simultaneously; (2) to determine the absorbance ratio at $272 \mathrm{~nm}$ (the maximum absorption of HCT) and $266.5 \mathrm{~nm}$ (the isosbestic wavelength); (3) to use the first-order derivative method. Thube et al. [11] also proposed three spectrophotometric methods for the simultaneous determination of LSP and HCT in a binary mixture: (1) to measure the absorbance at $235 \mathrm{~nm}$ and $271 \mathrm{~nm}$, corresponding to the absorbance maxima of LSP and HCT, respectively (the concentration of each drug was obtained by using the absorption values calculated for both drugs at these wavelengths); (2) to use the dual-wavelength principle in which the absorbance difference between two points on the mixture spectra was directly proportional to the concentration of the component of interest and independent of the interfering components; and (3) to describe and calculate the area under the curve between 265 and $282 \mathrm{~nm}$ for LSP and between 229 and $242 \mathrm{~nm}$ for HCT. The proposed methods were applied to marketed formulation. High-performance liquid chromatography was also applied to quantify these two compounds in pharmaceutical products [12-15]. Although HPLC delivers simultaneous determination, high cost prevents its application.

As the absorption spectra of HCT and LSP are overlapped, the Kalman filter algorithm using full spectra (Kalman-Excel method) [4] is employed in this study to quantify these two substances in pharmaceutical products simultaneously. The proposed method opens up the possibility of a fast and cheap technique for pharmaceutical analysis and testing.

\section{Materials and Methods}

\subsection{Instrument and Chemicals}

2.1.1. Instruments. A UV-Vis spectrophotometer Cary 60 (Agilent, USA) for spectral scanning $(190-990 \mathrm{~nm})$ is connected to a computer with Cary WinUV software for spectral data storage (in Excel spreadsheets). All the measurements were carried out at the Laboratory of Applied Chemistry, Department of Chemistry, University of Sciences, Vietnam

2.1.2. Chemicals. Hydrochlorothiazide standard $\left(\mathrm{C}_{7} \mathrm{H}_{8} \mathrm{ClN}_{3} \mathrm{O}_{4} \mathrm{~S}_{2}\right), 99.8 \%$ purity, was purchased from the National Institute of Drug Quality Control, standard Vietnamese pharmacopoeia (Code: C0219308.02). Losartan Potassium standard $\left(\mathrm{C}_{22} \mathrm{H}_{22} \mathrm{ClKN}_{6} \mathrm{O}\right), 99.9 \%$ purity, was obtained from the Institute of Drug Quality Control, Ho Chi
Minh City, standard Vietnamese pharmacopoeia (Lot No. 166090520). All other chemicals used were of analytical grade.

The stock solution of HCT $(50.0 \mu \mathrm{g} / \mathrm{mL})$ was prepared by dissolving $12.5 \mathrm{mg}$ of HCT standard in $150 \mathrm{~mL}$ of distilled water and ultrasonicated for $15 \mathrm{~min}$. The solution was then made up to $250 \mathrm{~mL}$ with distilled water. Twenty-five millilitres of the stock solution was diluted with $75 \mathrm{~mL}$ of distilled water to make a working solution of HCT $(12.5 \mu \mathrm{g} /$ $\mathrm{mL}$ ). The stock solution of LSP $(50.0 \mu \mathrm{g} / \mathrm{mL})$ (also acted as a working solution) was prepared by dissolving $12.5 \mathrm{mg}$ LSP standard in distilled water and making up to $250 \mathrm{~mL}$.

2.2. Sample Preparation. In this study, Splozarsin Plus tablets (Co. Ltd. SHINPOONG DAEWOO, Bien Hoa industrial zone, Dong Nai, Vietnam, batch code 9003, manufactured date 5 June 2019, expired date 5 June 2021) were used for the method validation. The reference amount of LSP and HCT on the label is $50.0 \mathrm{mg}$ and $12.5 \mathrm{mg}$, respectively.

Twenty tablets with an average weight of $253.4 \mathrm{mg}$ were ground to a fine powder and mixed well. A particular amount of the powder $(\mathrm{m})$ was dissolved in $150 \mathrm{~mL}$ distilled water and ultrasonicated for $30 \mathrm{~min}$ before filtering to make up a $250 \mathrm{~mL}$ solution. Ten millilitres of the solution was diluted to $100 \mathrm{~mL}$ with distilled water for measurements.

The amount of each target compound in a tablet is expressed via $\mathrm{mg} /$ tablet and calculated according to the following equation:

$$
\begin{aligned}
\frac{\mathrm{mg}}{\text { tablet }} & =C_{i} \times 100 \times\left(\frac{250}{10}\right) \times\left(\frac{M}{m}\right) \times\left(\frac{1}{1000}\right) \\
& =2.5 \times C_{i} \times\left(\frac{M}{m}\right),
\end{aligned}
$$

where $C_{i}(\mu \mathrm{g} / \mathrm{mL})$ is the concentration of compound $i$ in the final solution; $M(\mathrm{mg})$ is the average weight of the tablets; and $m(\mathrm{mg})$ is the weight of the powder.

2.3. Analytical Procedure. To determine HCT and LSP simultaneously, we utilized the Kalman filter algorithm with full-spectral measurements. The Visual Basic for Applications, a programming language written on the basis of Microsoft Excel 2016, was used for data treatment [4].

Briefly, the standard solutions of individual compounds and their actual sample solutions were subjected to record molecular absorption spectra (scanned from 220 to $300 \mathrm{~nm}$ wavelength at $1.0 \mathrm{~nm}$ intervals). The achieved data were saved as .csv files and extracted to the computer as Excel sheets. The developed Kalman-Excel program was applied to determine the concentrations and respective errors.

\subsection{Method Validation}

2.4.1. Relative Error (RE\%). The relative error (RE\%) between concentrations is calculated according to the following equation [16]: 


$$
\mathrm{RE}(\%)=\frac{\left(C-C_{0}\right)}{100} \times C_{0},
$$

where $C$ is the measured concentration $(\mu \mathrm{g} / \mathrm{mL})$ and $C_{0}$ is the concentration of the standard solution $(\mu \mathrm{g} / \mathrm{mL})$.

2.4.2. Limit of Detection (LOD) and Limit of Quantification (LOQ). Measurements are made on a minimum of seven aliquots $(n \geq 7)$ of a prepared sample solution that has a concentration near the expected limit of detection [16]. The developed Kalman-Excel program was applied to determine the concentrations of HCT and LSP in the seven aliquots when using their spectrum data and spectrum data of the standard solutions of HCT and LSP. The LOD and LOQ were then calculated by the following formula:

$$
\begin{aligned}
& \mathrm{LOD}=3.3 \times \mathrm{SD}, \\
& \mathrm{LOQ}=10 \times \mathrm{SD},
\end{aligned}
$$

where SD is the standard deviation of seven replicates.

2.4.3. Repeatability (RSD\%). The repeatability of the analytical method is assessed via relative standard deviation [16-18]:

$$
\operatorname{RSD}(\%)=\frac{\mathrm{SD} \times 100}{C_{m}},
$$

where $\mathrm{SD}$ is the standard deviation and $C_{\mathrm{m}}$ is the mean concentration of $n$ replicates.

The RSD value is acceptable if lower than $1 / 2 \mathrm{RSD}_{\text {Horwitz }}$ [19], in which $\mathrm{RSD}_{\text {Horwitz }}$ is calculated according to the following equation:

$$
\operatorname{RSD}_{\text {Horwitz }}=2^{(1-0.5 \times \lg C)},
$$

where $C$ is expressed as a fraction (e.g., $C=5 \mu \mathrm{g}$ / $\left.\mathrm{mL}=5 \times 10^{-6}\right)$.

2.4.4. Trueness. The trueness of the analytical method was verified via the method's recovery and the mean values of the developed method and a standard method.

(i) Recovery. The mean recovery is determined by assessing spiked samples at three different levels (three replicates per level) of each target compound, namely, 0.500, 1.000, and $1.500 \mu \mathrm{g} / \mathrm{mL}$ for HCT and $2.000,4.000$, and $6.000 \mu \mathrm{g} / \mathrm{mL}$ for LSP. The recovery rate is calculated by the following equation:

$$
\operatorname{Rev}(\%)=\frac{\left(C_{2}-C_{1}\right) \times 100}{C_{s}},
$$

where $C_{2}(\mu \mathrm{g} / \mathrm{mL})$ is the measured concentration of the spiked sample; $C_{1}(\mu \mathrm{g} / \mathrm{mL})$ is the measured concentration of the original sample (sample without spiking); and $C_{\mathrm{s}}(\mu \mathrm{g} /$ $\mathrm{mL}$ ) is the spiked concentration.

In this study, Splozarsin Plus tablets were used as the original sample. Three-fifths of the average tablet weight (3/ $5 \times M)$ were taken for each sample. The standard solutions of
HCT $(5.000 \mu \mathrm{g} / \mathrm{mL})$ and LSP $(20.000 \mu \mathrm{g} / \mathrm{mL})$ were also prepared at the same time for spectral measurements. The developed Kalman-Excel program was applied to quantify the concentration of HCT and LSP in the samples simultaneously. The acceptable recovery rate is from $85 \%$ to $110 \%$ [18].

(ii) Comparing Two Sample Means Performed By KalmanExcel Method and Standard HPLC Method. According to Harvey [20], the trueness of an analytical method could be evaluated by analyzing $n_{1}$ and $n_{2}$ replicates with the developed method and the standard method. The mean values achieved from the two analytical methods are compared with the $t$-test. The Splozarsin Plus tablets were sent to the Drug, Cosmetic and Food Quality control Center of Thua Thien Hue Province for analysis with the HPLC method. Hydrochlorothiazide and Losartan Potassium were quantified following the Vietnam Pharmacopoeia V guideline [20]. The Splozarsin Plus solutions were prepared (described in Section 2.2) and analyzed with the developed KalmanExcel method (described in Section 2.3) with three replicates. The $t$-test was used for evaluation: when the variances for the two analyses are not significantly different if the experimental $t$ value is lower than the $t$ value at risk of 0.05 and $\left(n_{1}+n_{2-2}\right)$ degrees of freedom, the mean values achieved from the two methods are not significantly different.

\section{Results and Discussion}

3.1. Relative Errors and Repeatability. Seven mixtures of HCT and LSP standards with different concentration ratios were prepared from the standard solutions of HCT $(12.500 \mu \mathrm{g} / \mathrm{mL})$ and LSP $(50.000 \mu \mathrm{g} / \mathrm{mL})$. The mixtures and the standard solutions were subjected to analysis with the Kalman-Excel method, as described in Section 2.3. The absorption spectra are shown in Figure 1.

At different HCT and LSP concentration ratios, the RE values between reference concentrations and their measured concentrations vary from -1.55 to $1.93 \%$ (Table 1 ). In addition, the RSD values are far lower than the respective 1/ $2 \mathrm{RSD}_{\mathrm{H}}$ values. This finding indicates the good performance of the Kalman-Excel method for the simultaneous determination of HCT and LSP in standard mixtures.

\subsection{Method Validation on Pharmaceutical Tablets}

3.2.1. Quantification of HCT and LSP in Splozarsin Plus Tablet and Method Repeatability. A Splozarsin Plus powder weighting $253.4 \mathrm{mg}$ (after grinding and mixing) was prepared as described in Section 2.2 and analyzed as described in Section 2.3. The amount of HCT and LSP in the Splozarsin Plus tablet was determined following equation (1). The absorption spectra of the sample and standard solutions are illustrated in Figure 2.

The results in Table 2 show that the Kalman-Excel method to determine HCT and LSP in a pharmaceutical product simultaneously yields good repeatability (RSDs vary from 0.27 to $0.3 \%$ for two studied compounds). The average amounts of HCT and LSP quantified in Splozarsin Plus tablet 


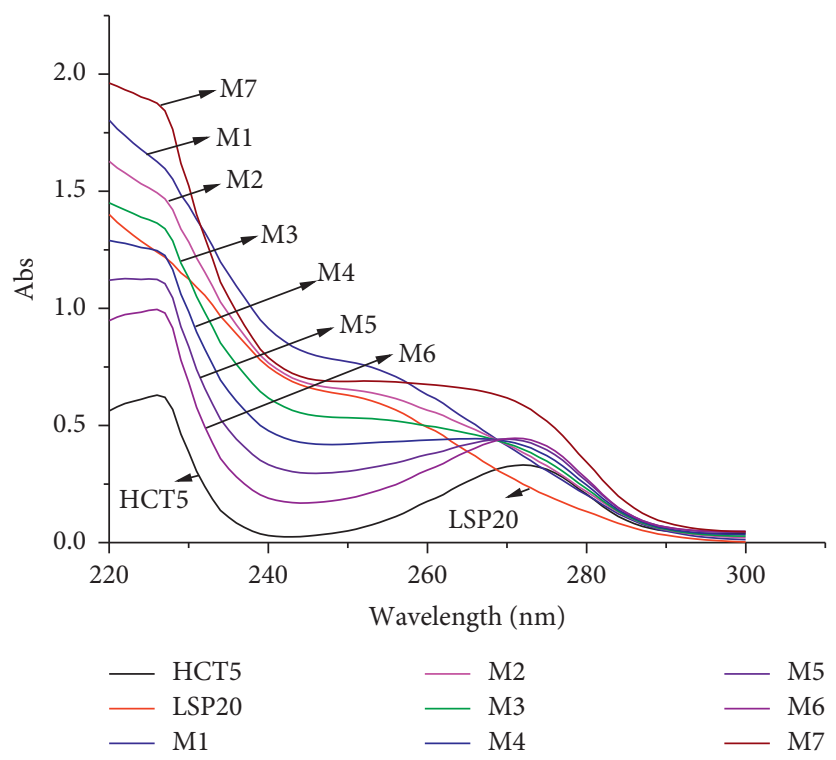

FIGURE 1: Absorption spectra of the HCT and LSP standards and their mixtures at different concentration ratios. HCT5: HCT standard solution of $5.000 \mu \mathrm{g} / \mathrm{mL}$; LSP20: LSP standard solution of $20.000 \mu \mathrm{g} / \mathrm{mL} ; \mathrm{M} 1:$ mixture of HCT $1.000 \mu \mathrm{g} / \mathrm{mL}+\mathrm{LSP} 24.000 \mu \mathrm{g} / \mathrm{mL} ; \mathrm{M} 2$ : mixture of HCT $2.000 \mu \mathrm{g} / \mathrm{mL}+$ LSP $20.000 \mu \mathrm{g} / \mathrm{mL}$; M3: mixture of HCT $3.000 \mu \mathrm{g} / \mathrm{mL}+\mathrm{LSP} 16.000 \mu \mathrm{g} / \mathrm{mL}$; M4: mixture of HCT 4.000 $\mu \mathrm{g} /$ $\mathrm{mL}+\mathrm{LSP} 12.000 \mu \mathrm{g} / \mathrm{mL} ; \mathrm{M} 5:$ mixture of HCT $5.000 \mu \mathrm{g} / \mathrm{mL}+\mathrm{LSP} 8.000 \mu \mathrm{g} / \mathrm{mL} ; \mathrm{M} 6:$ mixture of HCT $6.000 \mu \mathrm{g} / \mathrm{mL}+\mathrm{LSP} 4.000 \mu \mathrm{g} / \mathrm{mL}$; M7: mixture of HCT $5.000 \mu \mathrm{g} / \mathrm{mL}+$ LSP $20.000 \mu \mathrm{g} / \mathrm{mL}$.

TABLE 1: Relative errors and repeatability of the Kalman-Excel method.

\begin{tabular}{|c|c|c|c|c|c|c|c|c|}
\hline \multirow[b]{2}{*}{$\begin{array}{l}\text { Sample } \\
\text { name }\end{array}$} & \multirow[b]{2}{*}{$\begin{array}{l}\text { Conc. ratios } \\
\text { (HCT/LSP) }\end{array}$} & \multirow[b]{2}{*}{$n$} & \multicolumn{3}{|c|}{ HCT } & \multicolumn{3}{|c|}{ LSP } \\
\hline & & & $\begin{array}{c}C_{\mathrm{HCT}} \\
(\mu \mathrm{g} / \mathrm{mL})\end{array}$ & $\mathrm{RE}(\%)$ & $\begin{array}{c}\mathrm{RSD}\left(1 / 2 \mathrm{RSD}_{\mathrm{H}}\right) \\
(\%)\end{array}$ & $\begin{array}{c}C_{\mathrm{LSP}} \\
(\mu \mathrm{g} / \mathrm{mL})\end{array}$ & RE (\%) & $\begin{array}{c}\mathrm{RSD}\left(1 / 2 \mathrm{RSD}_{\mathrm{H}}\right) \\
(\%)\end{array}$ \\
\hline \multirow{4}{*}{ M1 } & \multirow{4}{*}{$1: 24$} & 1 & 1.002 & 0.20 & \multirow{4}{*}{$\begin{array}{c}0.30 \\
(8.00)\end{array}$} & 24.206 & 0.86 & \multirow{4}{*}{$\begin{array}{c}0.07 \\
(4.96)\end{array}$} \\
\hline & & 2 & 0.996 & -0.40 & & 24.238 & 0.99 & \\
\hline & & 3 & 0.999 & -0.10 & & 24.229 & 0.95 & \\
\hline & & Average & 0.990 & -0.10 & & 24.224 & 0.93 & \\
\hline \multirow{4}{*}{ M2 } & \multirow{4}{*}{$2: 20$} & 1 & 1.981 & -0.95 & \multirow{4}{*}{$\begin{array}{l}0.175 \\
(7.21)\end{array}$} & 20.115 & 0.57 & \multirow{4}{*}{$\begin{array}{c}0.05 \\
(5.10)\end{array}$} \\
\hline & & 2 & 1.981 & -0.95 & & 20.112 & 0.56 & \\
\hline & & 3 & 1.975 & -1.25 & & 20.131 & 0.66 & \\
\hline & & Average & 1.979 & -1.05 & & 20.119 & 0.6 & \\
\hline \multirow{4}{*}{ M3 } & \multirow{4}{*}{$3: 16$} & 1 & 2.982 & -0.60 & \multirow{4}{*}{$\begin{array}{l}0.166 \\
(6.78)\end{array}$} & 15.961 & -0.24 & \multirow{4}{*}{$\begin{array}{c}0.06 \\
(5.27)\end{array}$} \\
\hline & & 2 & 2.973 & -0.90 & & 15.971 & -0.18 & \\
\hline & & 3 & 2.974 & -0.87 & & 15.979 & -0.13 & \\
\hline & & Average & 2.976 & -0.79 & & 15.970 & -0.18 & \\
\hline \multirow{4}{*}{ M4 } & \multirow{4}{*}{$4: 12$} & 1 & 3.975 & -0.62 & \multirow{4}{*}{$\begin{array}{c}0.14 \\
(6.49)\end{array}$} & 12.067 & 0.56 & \multirow{4}{*}{$\begin{array}{c}0.02 \\
(5.50)\end{array}$} \\
\hline & & 2 & 3.966 & -0.85 & & 12.071 & 0.59 & \\
\hline & & 3 & 3.965 & -0.87 & & 12.072 & 0.60 & \\
\hline & & Average & 3.969 & -0.78 & & 12.070 & 0.58 & \\
\hline \multirow{4}{*}{ M5 } & \multirow{4}{*}{$5: 08$} & 1 & 5.008 & 0.16 & \multirow{4}{*}{$\begin{array}{c}0.20 \\
(6.28)\end{array}$} & 8.019 & 0.24 & \multirow{4}{*}{$\begin{array}{c}0.10 \\
(5.85)\end{array}$} \\
\hline & & 2 & 4.991 & -0.18 & & 8.035 & 0.44 & \\
\hline & & 3 & 4.990 & -0.20 & & 8.031 & 0.39 & \\
\hline & & Average & 4.996 & -0.07 & & 8.028 & 0.36 & \\
\hline \multirow{4}{*}{ M6 } & \multirow{4}{*}{$6: 04$} & 1 & 5.921 & -1.32 & 0.21 & 4.064 & 1.60 & \multirow{4}{*}{$\begin{array}{c}0.17 \\
(6.49)\end{array}$} \\
\hline & & 2 & 5.897 & -1.72 & $(6.11)$ & 4.074 & 1.85 & \\
\hline & & 3 & 5.904 & -1.60 & & 4.077 & 1.93 & \\
\hline & & Average & 5.907 & -1.55 & & 4.072 & 1.79 & \\
\hline \multirow{4}{*}{ M7 } & \multirow{4}{*}{$5: 20$} & 1 & 4.990 & -0.20 & 0.15 & 20.203 & 1.02 & 0.06 \\
\hline & & 2 & 4.975 & -0.50 & $(6.28)$ & 20.224 & 1.12 & $(5.10)$ \\
\hline & & 3 & 4.980 & -0.40 & & 20.220 & 1.10 & \\
\hline & & Average & 4.982 & -0.37 & & 20.216 & 1.08 & \\
\hline
\end{tabular}

$\mathrm{RSD}_{\mathrm{H}}$ : RSD value calculated from the Horwitz function; M1: mixture of HCT $1.000 \mu \mathrm{g} / \mathrm{mL}+\mathrm{LSP} 24.000 \mu \mathrm{g} / \mathrm{mL} ; \mathrm{M} 2: \mathrm{mixture}$ of HCT $2.000 \mu \mathrm{g} / \mathrm{mL}+\mathrm{LSP}$ $20.000 \mu \mathrm{g} / \mathrm{mL}$; M3: mixture of HCT $3.000 \mu \mathrm{g} / \mathrm{mL}+\mathrm{LSP} 16.000 \mu \mathrm{g} / \mathrm{mL}$; M4: mixture of HCT $4.000 \mu \mathrm{g} / \mathrm{mL}+\mathrm{LSP} 12.000 \mu \mathrm{g} / \mathrm{mL}$; M5: mixture of HCT 5.000 $\mu \mathrm{g} /$ $\mathrm{mL}+\mathrm{LSP} 8.000 \mu \mathrm{g} / \mathrm{mL}$; M6: mixture of HCT $6.000 \mu \mathrm{g} / \mathrm{mL}+\mathrm{LSP} 4.000 \mu \mathrm{g} / \mathrm{mL}$; M7: mixture of HCT 5.000 $\mu \mathrm{g} / \mathrm{mL}+\mathrm{LSP} 20.000 \mu \mathrm{g} / \mathrm{mL}$. 


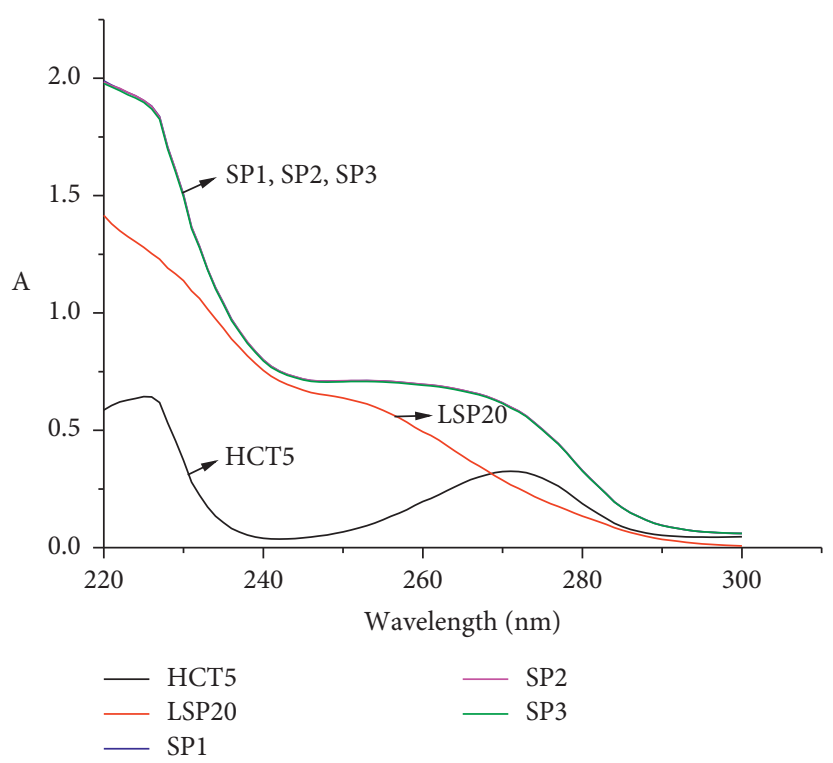

Figure 2: Absorption spectra of HCT and LSP standard solutions and Splozarsin Plus sample solutions. HCT5: standard solution of HCT $5.000 \mu \mathrm{g} / \mathrm{mL}$; LSP20: standard solution of LSP $20.000 \mu \mathrm{g} / \mathrm{mL}$; SP1, SP2, SP3: Splozarsin Plus sample solutions.

TAble 2: Measured amounts of HCT and LSP in Splozarsin Plus tablet and the respective RSD values.

\begin{tabular}{lcccc}
\hline Sample name & \multicolumn{2}{c}{ HCT $^{*}$} & LSP* & CLSP $(\mu \mathrm{g} / \mathrm{mL})$ \\
\hline SP1 & $C_{\mathrm{HCT}}(\mu \mathrm{g} / \mathrm{mL})$ & Content $(\mathrm{mg} / \mathrm{tablet})$ & 20.033 & 50.08 \\
SP2 & 4.978 & 12.45 & 20.042 & 50.11 \\
SP3 & 4.975 & 12.44 & 19.942 & 49.86 \\
Average & 4.953 & 12.38 & 20.01 & 50.02 \\
RSD\% & 4.969 & 12.42 & 0.27 & 0.27 \\
\hline
\end{tabular}

${ }^{*}$ The amounts of LSP and HCT on the Splozarsin Plus label were $50.0 \mathrm{mg}$ and $12.5 \mathrm{mg}$, respectively.

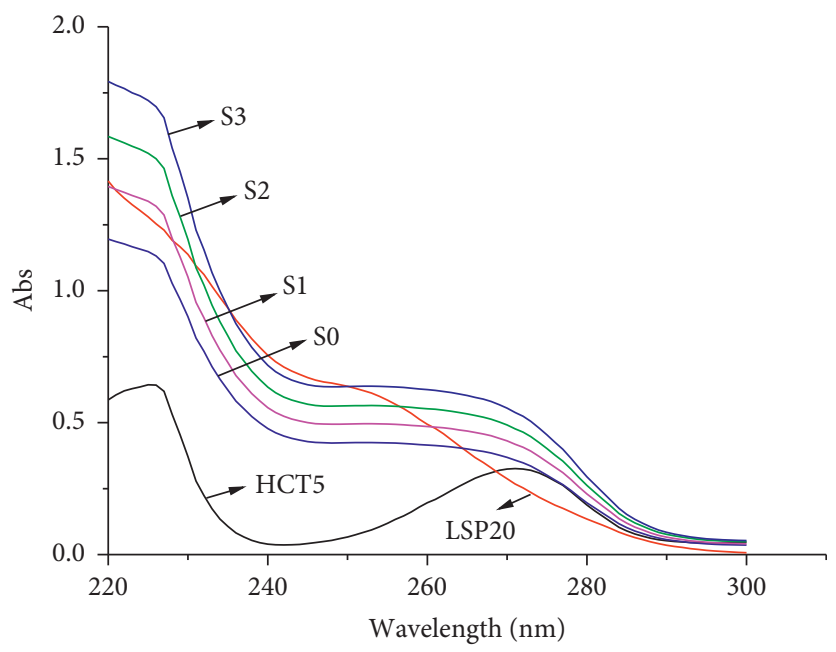

FIGURE 3: Absorption spectra of standard solutions, spiked samples, and original sample. HCT5: standard solution of HCT $5 \mu \mathrm{g} / \mathrm{mL}$; LSP20: standard solution of LSP $20 \mu \mathrm{g} / \mathrm{mL}$; S0: original samples; S1: spiked sample level 1 (HCTad $=0.500 \mu \mathrm{g} / \mathrm{mL}, \mathrm{LSPad}=2.000 \mu \mathrm{g} / \mathrm{mL}) ; \mathrm{S} 2: \mathrm{spiked}$ sample level $2(\mathrm{HCTad}=1.000 \mu \mathrm{g} / \mathrm{mL}, \mathrm{LSPad}=4.000 \mu \mathrm{g} / \mathrm{mL}) ; \mathrm{S} 3:$ spiked sample level $3(\mathrm{HCTad}=1.500 \mu \mathrm{g} / \mathrm{mL}, \mathrm{LSPad}=6.000 \mu \mathrm{g} / \mathrm{mL})$. 
TABle 3: Recovery of HCT and LSP in Splozarsin Plus.

\begin{tabular}{|c|c|c|c|c|c|c|c|c|}
\hline \multirow{2}{*}{ Sample } & \multicolumn{4}{|c|}{ HCT } & \multicolumn{4}{|c|}{ LSP } \\
\hline & $C_{\text {spiked }}(\mu \mathrm{g} / \mathrm{mL})$ & $C_{\text {measured }}(\mu \mathrm{g} / \mathrm{mL})$ & $\operatorname{Rev}(\%)$ & RSD (\%) & $C_{\text {spiked }}(\mu \mathrm{g} / \mathrm{mL})$ & $C_{\text {measured }}(\mu \mathrm{g} / \mathrm{mL})$ & $\operatorname{Rev}(\%)$ & RSD (\%) \\
\hline $\mathrm{S}_{01}$ & & 3.003 & - & & 0 & 11.997 & - & \\
\hline $\mathrm{S}_{02}$ & 0 & 3.009 & - & 0.167 & 0 & 11.991 & - & 0.029 \\
\hline $\mathrm{S}_{03}$ & & 3.013 & - & & 0 & 11.997 & - & \\
\hline$S_{11}$ & & 3.512 & 101.80 & & 2.000 & 13.962 & 98.25 & \\
\hline $\mathrm{S}_{12}$ & 0.500 & 3.508 & 99.80 & 0.066 & 2.000 & 13.964 & 98.65 & 0.014 \\
\hline $\mathrm{S}_{13}$ & & 3.508 & 99.00 & & 2.000 & 13.966 & 99.45 & \\
\hline$\overline{S_{21}}$ & & 3.996 & 99.30 & & 4.000 & 15.887 & 97.25 & \\
\hline $\mathrm{S}_{22}$ & 1.000 & 4.004 & 99.50 & 0.100 & 4.000 & 15.882 & 97.28 & 0.017 \\
\hline $\mathrm{S}_{23}$ & & 4.000 & 98.70 & & 4.000 & 15.886 & 97.73 & \\
\hline$S_{31}$ & & 4.515 & 100.80 & & 6.000 & 17.973 & 99.60 & \\
\hline $\mathrm{S}_{32}$ & 1.500 & 4.520 & 100.73 & 0.056 & 6.000 & 17.973 & 99.73 & 0.010 \\
\hline $\mathrm{S}_{33}$ & & 4.517 & 100.27 & & 6.000 & 17.970 & 99.88 & \\
\hline
\end{tabular}

TABLE 4: The validation results of other methods in comparison with this Kalman-Excel method for the determination of HCT and LSP in tablets.

\begin{tabular}{|c|c|c|c|c|c|c|c|}
\hline Sources & Method & Solvent & $\begin{array}{c}\text { Range of } \\
\text { concentration } \\
(\mu \mathrm{g} / \mathrm{mL}) \\
\mathrm{HCT} \\
\text { LSP }\end{array}$ & $\begin{array}{l}\text { LOD } \\
(\mu \mathrm{g} / \mathrm{mL}) \\
\mathrm{HCT} \\
\text { LSP }\end{array}$ & $\begin{array}{l}\text { LOQ } \\
(\mu \mathrm{g} / \mathrm{mL}) \\
\mathrm{HCT} \\
\text { LSP }\end{array}$ & $\begin{array}{c}\text { Rev }(\%) \\
\text { HCT } \\
\text { LSP }\end{array}$ & $\begin{array}{c}\text { RSD (\%) } \\
\text { HCT } \\
\text { LSP }\end{array}$ \\
\hline [8] & PLS, spectrophotometry & $\mathrm{H}_{2} \mathrm{O}$ & $\begin{array}{c}1.06-5.70 \\
4.0-22.2\end{array}$ & $\begin{array}{l}0.06 \\
0.21\end{array}$ & $\begin{array}{l}0.14 \\
0.49\end{array}$ & $\begin{array}{l}95.6 \\
93.5\end{array}$ & $\begin{array}{l}0.6 \\
1.7\end{array}$ \\
\hline [9] & $\begin{array}{l}\text { 1/Vierordt's method } \\
\text { 2/absorbance ratio } \\
\text { method }\end{array}$ & $0.01 \mathrm{~N} \mathrm{HCl}$ & $\begin{array}{l}0.563-27.27 \\
0.708-22.22\end{array}$ & $\begin{array}{l}0.233 \\
0.708\end{array}$ & $\begin{array}{l}0.186 \\
0.563\end{array}$ & $98.13-99.69$ & $<0.246$ \\
\hline [10] & $\begin{array}{l}\text { 1/simultaneous equation } \\
\text { 2/ratio of absorbance } \\
\text { 3/first-order derivative } \\
\text { method }\end{array}$ & Methanol & $\begin{array}{c}1 / 1-20 \\
5-25 \\
2 / 1-25 \\
5-80 \\
3 / 1-40 \\
1-30\end{array}$ & 0.5 & 1.97 & $\approx 99$ & 0.57 \\
\hline$[11]$ & $\begin{array}{l}\text { 1/simultaneous equation } \\
\text { 2/dual wavelength } \\
\text { 3/area under curve }\end{array}$ & & $5-30$ & $\begin{array}{c}0.30 \\
0.30(3 \\
\text { methods) }\end{array}$ & $\begin{array}{c}0.90 \\
0.90(3 \\
\text { methods })\end{array}$ & $98.7-100.3$ & $\begin{array}{c}0.49-0.57 \\
0.49-0.57(3 \\
\text { methods })\end{array}$ \\
\hline$[12]$ & $\begin{array}{c}\text { Microemulsion } \\
\text { liquid chromatography }\end{array}$ & $\begin{array}{c}\text { Mobile } \\
\text { phase SDS, n-butanol, } \\
\text { n-octane, water, and } \\
\text { acetonitrile }\end{array}$ & $\begin{array}{c}2.5-12.5 \\
10.0-60.0\end{array}$ & $\begin{array}{l}0.03 \\
0.04\end{array}$ & $\begin{array}{c}0.1 \\
0.15\end{array}$ & $\begin{array}{c}98.9 \\
101\end{array}$ & $<1.4$ \\
\hline [13] & RP-HPLC & $\begin{array}{l}\text { Acetonitrile and } \\
\text { formic acid }\end{array}$ & $\begin{array}{l}2-10 \\
5-50\end{array}$ & $\begin{array}{c}0.5 \text { for HCT } \\
\text { and LSP }\end{array}$ & $\begin{array}{c}1.5 \text { for HCT } \\
\text { and LSP }\end{array}$ & $\begin{array}{c}96 \\
92 \\
99.55-\end{array}$ & $\begin{array}{l}<0.61 \\
<1.22\end{array}$ \\
\hline [14] & RP-HPLC & $\begin{array}{l}\text { Acetonitrile and } \\
\text { formic acid }\end{array}$ & $\begin{array}{l}1.0-300.3 \\
4.4-240.2\end{array}$ & $\begin{array}{l}0.304 \\
0.232\end{array}$ & $\begin{array}{l}0.921 \\
0.734\end{array}$ & $\begin{array}{l}100.67 \\
98.44- \\
100.48\end{array}$ & $\begin{array}{l}0.24-0.61 \\
0.19-1.22\end{array}$ \\
\hline $\begin{array}{l}\text { This } \\
\text { study }\end{array}$ & $\begin{array}{l}\text { Spectrophotometry with } \\
\text { Kalman filter algorithm }\end{array}$ & $\mathrm{H}_{2} \mathrm{O}$ & $\begin{array}{c}1.0-6.0 \\
4.0-24.0\end{array}$ & $\begin{array}{l}0.037 \\
0.228\end{array}$ & $\begin{array}{l}0.12 \\
0.76\end{array}$ & $\begin{array}{c}98.7-101.8 \\
97.25-99.88\end{array}$ & $\begin{array}{l}<0.167 \text { for } \\
\text { HCT and LSP }\end{array}$ \\
\hline
\end{tabular}

are $12.42 \pm 0.09 \mathrm{mg}$ and $50.02 \pm 0.34 \mathrm{mg}$, respectively. These values agree well with the reference content on the label (12.5 $\mathrm{mg}$ and $50 \mathrm{mg}$, respectively). They also comply with the quality standards of the Vietnamese Ministry of Health, which allows the content of the ingredients in this type of tablets as follows: HCT: $12.50 \mathrm{mg} \pm 7.5 \%$ (11.56-13.44 mg), LSP: $50.00 \mathrm{mg} \pm 5 \%(47.5-52.5 \mathrm{mg})$ [21].

\subsubsection{Trueness, $L O D$, and $L O Q$ of Method}

(1) Recovery of the Method. The absorption spectra of standard solutions and spiked samples are demonstrated in Figure 3. The results of recovery are shown in Table 3.

The recovery of the Kalman-Excel method is approximately $100 \%$ for the studied compounds with good 
kalman filter algorithm," Advances in Materials Science and Engineering, vol. 2019, Article ID 5719651, 9 pages, 2019.

[5] H. W. Darwish, A. H. Bakheit, A. S. Abdelhameed, and R. A. Mothana, "Application of classical least squares, principal component regression and partial least squares methods for simultaneous spectrophotometric determination of rutin and ascorbic acid in their combined dosage form," Life Science Journal, vol. 10, no. 4, 2013.

[6] V. R. Galande, K. G. Baheti, S. Indraksha, and M. H. Dehghan, "Estimation of amlodipine besylat, valsartan and hydrochlorothiazide in bulk mixture and tablet by UV spectrophotometry," Indian Journal of Pharmaceutical Sciences, vol. 74, no. 1, pp. 18-23, 2012.

[7] M. H. Abdel-Hay, S. M. Galal, and M. A. A. Ragab, “Application of derivative and derivative-ratio spectrophotometry in the determination of a binary mixture of naproxen and diflunisal and a ternary mixture of orphenadrine, caffeine and aspirin," Taiwan Pharmaceutical Journal, vol. 59, no. 4, pp. 157-170, 2007.

[8] R. M. Maggio, P. M. Castellano, and T. S. Kaufman, "A multivariate approach for the simultaneous determination of losartan potassium and hydrochlorothiazide in a combined pharmaceutical tablet formulation," Analytical and Bioanalytical Chemistry, vol. 391, no. 8, pp. 2949-2955, 2008.

[9] P. Rathee, S. Rathee, D. Rathee, and H. Chaudhary, "Stability indicating UV-spectrophotometric methods for simultaneous determination of losartan potassium and hydrochlorothiazide in pharmaceuticals," Eurasian Journal of Analytical Chemistry, vol. 4, no. 1, pp. 98-109, 2009.

[10] K. Rao, N. Keshar, and M. Panda, "Spectrophotometric methods for the simultaneous estimation of losartan potassium and hydrochlorothiazide in tablet dosage forms," Chronicles of Young Scientists, vol. 2, no. 3, p. 155, 2011.

[11] C. Thube, J. Dhagude, and P. Y. Pawar, "Simultaneous estimation and validation of losartan potassium and hydrochlorothiazide in bulk and tablet dosage form by using different spectrophotometric method," Der Pharma Chemica, vol. 6 , no. 2, pp. 24-30, 2014.

[12] L. Li, C. Lai, X. Xuan, C. Gao, and N. Li, "Simultaneous determination of hydrochlorothiazide and losartan potassium in osmotic pump tablets by microemulsion liquid chromatography," Journal of Chromatographic Science, vol. 54, no. 8, pp. 1415-1420, 2016.

[13] M. Nidhal, S. Mohammed, H. R. Abdo, and H. M. Hassan, "Method development and validation of simultaneous determination of hydrochlorothiazide and losartan in tablet dosage form by RP-HPLC," International Journal of Pharmaceutical Sciences and Research, vol. 10, no. 1, pp. 227-231, 2019.

[14] T. Srinivasu and M. Mathrusri Annapurna, "A new stability indicating RP-HPLC method for the analysis of losartan and hydrochlorothiazide tablets," Journal of Chemical and Pharmaceutical Sciences, vol. 10, no. 2, pp. 798-802, 2017.

[15] N. Erk, "Analysis of binary mixtures of losartan potassium and hydrochlorothiazide by using high performance liquid chromatography, ratio derivative spectrophotometric and compensation technique," Journal of Pharmaceutical and Biomedical Analysis, vol. 24, pp. 603-611, 2001.

[16] P. M. Berthouex and L. C. Brown, Statistics for Environmental Engineerspp. 123-127, Lewis Publishers, Boca Raton, FL, USA, 2nd edition, 2002.

[17] I. Taverniers, M. De Loose, and E. Van Bockstaele, “Trends in quality in the analytical laboratory. II. analytical method validation and quality assurance," TrAC Trends in Analytical Chemistry, vol. 23, no. 8, pp. 535-552, 2004.

[18] AOAC International, AOAC ${ }^{\circledR}$ Guidelines for Single Laboratory Validation of Chemical Methods for Dietary Supplements and Botanicals, AOAC International, Gaithersburg, MD, USA, 2012.

[19] M. Thompson and P. J. Lowthian, "A horwitz-like function describes precision in a proficiency test," The Analyst, vol. 120, no. 2, pp. 271-272, 1995.

[20] D. Harvey, Morden Analytical Chemistrypp. 80-93, McGrawHill, New York, NY, USA, 1st edition, 2000.

[21] Ministry of Health, Vietnamese Pharmacopoeia V, vol. 483, pp. 588-589, Medical Publishing House, Hanoi, Vietnam, 2017. 